2. Bubins., C. 1963. A critical survey of European taxa in Ulvales. I. Capsosiphon, Percursaria, Blidingia, Enteromorpha. Opera Bot. 3:1-160.

3. Collins, F. S. 1903. The Ulvaceae of North America. Rhodora 5:I-31.

4. DeTon1, J. B. 1889. Sylloge algarum omnium hucusque cognitarum. Patavii. I (Chlorophycearum): $12+$ CXXXIX + 1315.

5. Gayrai. P. 1961. Sur la reproduction de Monosiroma obscurnem (Kütz.) J. Agardl. Compt. Rend. Acarl. Sci. Paris 252:1642-4.

6. 1962. Reproduction et développement de Monostroma obscturum (Kütz.) J. Agardh. Bull. Soc. Bot. France 109:53-9.

7. 1964. Sur le démembrement de l'actuel genre Momostroma Thuret (Chlorophycées, Ulotricales s. 1.). Compt. Rend. Acad. Sci. Paris 258:2149-52.

8. - 1965. Monostroma Thuret Ulunaria Rupr. emend. Gayral, Ulropsis Gayral (Chlorophycées. Ulotrichales): structure, reproduction. cycles, position systématique. Reu. Gen. Bot. 72:627-38.

9. Kornmann, P. \& Sahling, P. 1962. Zur Taxonomie und Entwicklung der Monostroma-Arten von Helgoland. Helgolïnd. Wiss. Weeresunters. 8:302-20.

10. KUNIEDA, H. 1934. On the life-history of Monostroma. Pror. Imp. Acat. Tokyo 10:103-6.

11. Postri.s. A. \& Ruprecht, F. J. 1840. Illustrationes il lgatum in itinere circa orben jussu imperatoris Nicolai $I$. Typis Eduardi Pratz. St. Petersburg. iv, $24 \mathrm{pp}$.
12. Printz, H, 1927. Chloroplyceae. In Engler \& Prant [el. A. Engler], Die natürlichen Pflumsenfamilien, Lciprig, ecl. 2, 3, iv + 463 pp.

13. Rosenving.e, L. K. 1893. Grønlands Havalgcr. Medtlel. om Grpnland. Copenhagen 3:76.5-981.

14. 1932. Note sur Monostroma obscurrum (Kütz.) J. Agardh. Rev. Algol. 6:297-300.

15. Ruprecht, F. J. 1851. Tange des ochotskischen Meeres. In A. T. von Middendorff, Sibirische Reise. Bot. 1:191-435.

16. Shintra, I, 1958. The characteristics of the thallus of Monostroma. J. Jap. Bot. 33:372-5.

17. Simith, G. M. 1947. On the reproduction of some Pacific Coast species of Ulva. Am. J. Bot. 34:8()-7.

18. Suneson, S. 1947. Notes on the life-history of Monostroma. Stensk Bot. Tidskr. 41:235-46.

19. Tatewnki, M. 1963. The Iife history of Monostroma fuscum var, splendens. Bot. Mag. Tokyo 76:381-i.

20. Thuret, G. 1854. Note sur la synonymie des Ulya lactuca et latissima L., suivie de quelques remarques sur la tribu des Ulvacées. Mem. Sor. Sri. Nat. Cherbourg 2: $17-32$.

21. Wirrrock, V. B. 1866. Försök till en monograph öfver Algslägtet Monostroma. (Thesis.) Stockholm. $66 \mathrm{pp}$.

29. Yamade, Y. \& SAIto, E. 1938. On some cullure experiments with the swarmers of certain species belonging to the Ulvaceace Sci. Pap. Inst. Algol. Res, Far. Sci., Hokkniclo $\mathrm{Im} f$. Lnit. 2:35-50.

23. YaMADA, Y. \& TATEWAKI, M. 1965. New findings on the Iife history of Monostroma zustericola Tilden. Sci. Pap. Inst. Algol. Res., Fuc. Sci., Hokkaido Imp. Lnir. 5:105-17.

\title{
POLYMORPHISM IN WASTOGLOIA
}

\author{
E. F. Stoermer \\ Great Lakes Research Division. The University of Michigan. Ann Arbor. Michigan 48104
}

\section{SUMMARY}

Cells in a wild population of a species belonging to the diatom gemus Mastogloia may form frustules of 2 strikingly different morphologic types during their vegetative life cycle. Total conversion from coarsely structured morphologic form to a more finely structured form takes place during a single division; hence no intergradations between the 2 forms are evident. Intact frustules with 1 valve of each type leave no reasonable doubt of the ability to make the change.

\section{INTRODUCTION}

One of the basic assumptions of systematics is relative stability of morphologic characteristics within a taxon. The general valiclity of this assumption is strikingly illustrated in the Bacillariophyta

\footnotetext{
${ }^{1}$ Contribution No. 73, Great Lakes Research Division, The University of Michigan, Ann Arbor. Michigan 48104 . Receized Jonuary is, 1967; revised April 3, 1967.
}

(diatoms) where the structure of the frustule, upon which modern systematic treatments are based, is remarkably constant throughout the vegetative phase of the life cycle of a given species under natural conditions. The average size of cells in a given populattion, at least of most species, is gradually reduced cluring a series of divisions (14) due to the rigidity of the overlapping thecae and the number in which new valves are formed $(18)$. Concomitantly, certain changes may occur in the shape of the frustules (6), but these changes follow a rather constant pattern and are well known for most diatom species. Von Stosch (19) has shown that this pattern may be upset by appropriate manipulations in culture. Sexual reproduction occurs, if conditions are favorable, when the cells reach a certain minimum size range which is more or less constant for a given species (4). The morphology of the zygote (auxospore) is usually quite unlike that of the vegetative cells and atypical 

frustules (Erstlingszellen) may be formed cluring the lirst few divisions following sexual reproduction. According to Hustedt (11), ecologic conditions at the time of auxospore formation may incluce changes in morphology of the frustule that are perpetuated cluring vegetative reproduction and give rise to populations having an internally constant morphology quite different from that of the parent population. Apparently such alterations in morphology are not incluced by genetic changes in the cells, as they will return to their typical form during subsequent sexual cycles if conditions are favorable. Such aberrant populations could be, and perhaps often are, described as new taxa. Lund (12) has shown that populations of a given species growing on soil tend to be smaller in average size than populations of the same species growing in an aquatic habitat. Occasionally deformed valves are found within an otherwise normal population. These deformities tend to be reproluced cluring vegetative cell division (3) so that a large proportion of isolated populations may have deformed valves. Such teratological forms are relative rarities and have excited the interest of numerous workers. In the genus Melosira, populalions of a given species maly exist in any of 2 or more morphologically dillerent lorms (13). These forms have been designated as alphat, beta, or gamma stattus. The lactors which cause this response have never been lully investigated experimentally but field observations show reduction in dissolved silica can cause change from the $\alpha$ to $\beta$ status.

\section{MATERIAIS AND MUTHOIS}

Matcrial used in this stuely was collected in an area locally known as Silver Lake Fen, located in the NW $1 / 4$ of section 32, TWP $100 \mathrm{~N}$, Range $38 \mathrm{~W}$, near the town of Lake Park in l)ickinson County. Iowa. The physiography of this area was reported by Anderson $(I)$, and its algal flora has been studied by Gasinwiler \&. Dodd (5). Collections of diatoms were taken from mats of Riccardia thalli which were kept moist by seepage water. After fresh material had been examined it was cleaned by Van der Werff's (21) method. mounted in Hyrax, and examined with a Bausch and Lomb $R$ series microscope fitted with $98 \times, 1.30$ N.A. fluorite oil immersion objective and ribbon filament illumination. Photographs were taken with a similar microscope using a $90 \times, 1.40$ N.A. apochromatic oil immersion olsjcctive and critical illumination.

\section{RESULTS}

After casual observation it appeared that among the many diatom species present in the collections there were 2 populations of Mastogloia, 1 belonging to $M$. grevillei Wm. Smith (Fig. 1-9) and another (11-19) generally referred to in the literature as $M$. clliptica var. dansei (Thwaites ex Wm. Smith) Cleve. The general shape of the valves, shape of the axial and central areas, structure of the raphe, and structure of the septae and locules are nearly identical in these 2 populations. There is, however, consiclerable difference in the number and apparent structure of the striae, a feature usually given considerable weight in systematic treatments of this group. Upon observation of a large number of specimens, it was discovered that certain intact frustules have 1 valve of each type (Fig. 10). Such cells are quite rare, comprising only about $0.5 \%$ of the specimens in which both valves are attached. The fact that the valves of most frustules are separated makes it difficult to determine the absolute frequency of such cells in the total population. Nonetheless, the presence of intact frustules having both types of valves makes it patently apparent that the 2 seemingly separate populations belong to the same genetic entity. The alteration in frustular morphology must take place during vegetative cell division and not during auxospore formation as the frustules having both types of valves are of the intermediate size range. It thus appears that environmental stress may cause alterations in the frustular morphology of certain naviculoid diatoms analogous to those observed in the centric genus Melosira.

\section{DISCUSSION}

There is relatively little doubt that the coarsely structured form in the population investigated has been consistently referred to as $M$. grevillei in the literature. It matches well the published descriptions of this entity and comparison with the Wm. Smith material in the cliatom herbarium of the Academy of Natural Sciences of Philadelphia leaves little cloubt as to its identity with Smith's taxon.

It is, however, evident that considerable confusion exists in the literature regarding specimens assignable to the finely structured form. The first area of conflict is in the identity of specimens assigned to $M$. elliptica var. dansei by various authors. Cleve's (2) variety is based on $M$. danse $i$ Thwaites ex Wm. Smith. It is interesting to note that Smith's (16) illustration of this entity (his Plate 62, Fig. 388) is placed in juxtaposition to his original illustration of $M$. grcuillei (Plate 62, Fig. 389) described in the same work. These illustrations and those of Grunow [in Van Heurck (7), Plate 4, Fig. 18, 20], also cited by Cleve in his description of $M$. elliptica var. dansei, could easily fit into the variation sequence shown by my specimens. I seriously doubt that Cleve would have reached the conclusion he did if he had been cognizant of the unusual structural alteration possible in $M$. grevillei as he notes in his description of $M$. grevillei (2): "This species resembles $M$. elliptica var. dansei but has a different structure of the valve." Without this knowledge Cleve's decision appears entirely tenable in that, to the best of our present knowledge, the structure of the valve surface is a more stable morphologic characteristic than valve shape (6). Although this generality should now be critically reexamined, the essential logic of Cleve's work is demonstrated by the wide acceptance his epithet gained among later workers.

Skvortzow (15) apparently correctly recognized 
the alfinities of the finely structured form to $M$. greville $i$ and published $M$. grevillei var. sinica based on specimens collected near Tientsin, China. Hustedt (8) considered this entity to be a synonym of $M$. elliptica var. dansci. He later (10) described M. recta based on specimens collected from 2 lakes in central Celebes. In his discussion of this species Hustedt refers to it specimens from Java that he had earlier (9) identified as M. elliptica var. dansei. Voigt (22) applied the name $M$. recta $H$ ust. to specimens he obtained from Karachi, Pakistan, and clescribed a new variety, M. recta var. pulchella, based on specimens from the same locality.

As I have already pointed out, the author of $M$. recta admitted to a certain amount of confusion between this entity and his concept of $M$. elliptica var. damsei. There are 2 primary differences between $M$. recta, as originally described and illustrated by Hustedt, and the finely structured form considered here: (1) the considerably greater maximum size of Hustedt's entity, and (2) the presence of a siliceous rib bordering the raphe which is cited as a definitive characteristic by Hustedt, but is not well developed in my specimens. Some of the other distinguishing characteristics such as unclulation of the raphe (compare present Fig. 13 to 15) and relitive size of the central area (compare present Fig. I2 to 16) put forth by Hustedt are rather ephemeral and must be treated with due caution. Returning to the major distinguishing characteristics, close inspection of Hustedt's figures arouses suspicion that he was not clealing with a true variation sequence. His Fig. 54 through 57 are consistent and agree rather closely to the range of variation shown by my specimens. Figure 58, on the other hand, is not consistent with the other figures and cloes not, in fact, agree with his description of the species. On the basis of the evidence available, $I$ am forced to the conclusion that the entity represented by $\mathrm{Hus-}$ tedt's Fig. 54 through 5\%, whatever its correct designation is, does not, in fact, reach a maximum sive of $80 \mu$. So far as the presence or absence of a rib bordering the raphe is concerned, determination of the thickness of structures in normal preparations is always more or less a matter of the investigator's juclgment. Probably no one is more eminently qualified than Hustedt to make such a judgment, but I must point out that at certain planes of focus (see present Fig. 17) my specimens give a refractive pattern that might be construed as a thickening in the region of the valve immediately bordering the raphe. This pattern is caused by the abutment of the thinner portion of the valve subtending the striae into the relatively thickened axial area and not by any marked thickening of the margins of the axial area (see reference 17 for analogous structure in $M$. grevillei).

The specimens of Voigt (22), reported as $M$. roctu and W. recta var. pulchella, appear to be fully comparable to my specimens, and I would consider the 2 illustrations furnished to represent the extremes in size range of a single entity.

If the interpretation developed so far is substantially correct, it follows that the morphology of the frustule in the species of Mastogloia investigated is controlled in some way by the level of total dissolved solids in the ambient water. Published reports of entities referable to the coarsely structured form come from habitats having relatively low levels of total clissolved solids, while entities referable to the more finely structured form are consistently reported from brackish or other highly mineralized waters. The only localities where the two may be expected to occur together are those in which rapid changes of ecological conditions force the transformation of an established population.

So far ats the nomenclature to be applied to the entity or entities represented in the population studied is concerned, one may admit to the possibility of three cases, as outlined brielly below:

\begin{tabular}{|c|c|c|c|}
\hline & I. & II. & III. \\
\hline W. grentlei & $=$ M. gretillei & & \\
\hline M. grequlle $i$ var sinien & ct forma & & \\
\hline M. damsei & non & $=M$. dansei & \\
\hline M. elliplica var. dansei & non & et formal & $=$ M. dansei \\
\hline H. recta & non & non & \\
\hline W. recta bar. pulchella & nom & $n o n$ & \\
\hline
\end{tabular}

Study of Smith's slides of $M$. dansei and of material lrom Pakistan containing $M$. recta does not completely resolve this problem, and the intermediate forms, if they clo indeed exist, are not present in the collections I have so far examined. Experimental evidence has proven difficult to develop as the organism in question has proven refractory to standard culture techniques. Although 1 consider the thircl of the alternatives presented above to be the likely one in light of the evidence at hand, I am reluctant to make a formal combination at the present time, as I have not had the opportunity to examine Thwaites' specimens of Dickieia dansei (20) which would become the nomenclatural type of any such combination.

\section{ACKNOWLEDGMENT}

This investigation was supported by U. S. Public Heaith Service fellowship WP20-447-02. I wish to express my appreciation to Dr. J. D. Dodd, of Iowa State University, who directed the investigation, and to Dr. C. W. Reimer, of the Academy of Natural Sciences of Philadelphia, for furnishing access to specimens of the entities treated and for valuable criticism. The conclusions drawn are the author's.

\section{REFERENCES}

1. Avoerson, W. A. 1943. A fen in nortliwestern lowa. Am. Widland Vat. 29:787-91. 
2. Crrve, P. T. 1895. Svnopsis of the naviculoid diatoms. Kongl. Sienska I'et.-Akad. Handl. Ny. Följd. 27(3):1-219.

3. Drum, R. W. 1964. Notes on Iowa cliatoms. VI. Frustular aberrations in Surirella ovalis. Proc. Iowa Acad. Sci. 71:51-5.

4. ERBEN, K. 1959. Untersuchungen äber Auxosporeentwicklung und Meioseatuslosung an Melosira nummmaloides (Dillw.) Agardh. Arch. Protistenk. 104:165-210.

5. Gashwiler, K. \& Dodd. J. D. 1961. Algae from the warm pools of Silver Lake Fen. Proc. Iowd Acal. Sci. 68:129-31.

(j. Geitler, L. 1932. Der Formwechsel der Pennaten Diatomeen (Kieselalgen). Arch. Protistenk. 78:1-226.

7. Heurck, H. van. 1880-81. Synopsis des Diatomées de Belgique, J. Ducaju \& Cie, Anvers.

8. Hustrdr, F. 1931-59. Die Kieselalgen. In Rabenhorst. L.. Kryptogamen-Flora, Akademische Verlagsgesellschaft Geest and Portig K. G., Leipzig, Bd. 7, Teil 2.

9. —_ 1937. Systematische und ökologische Untersuchungen uiber die Diatomeen-Flora von Java. Bali und Sumatra. Arch. Hydrobiol., Suppl. Bel. 15:187-295.

10. —_ 1942. Süsswasser-Diatomeen des indomalayischen Archipels und der Hawaii-Inseln. Intem. Ret. Hydrobiol. 42:1-1.52.

11. _- 1956. Kieselalgen (Diatomeen). Einfulhrmg in die Kleinlebuelt. Kosmos Verlag. Suttgart.

12. LuNo, J. W. (B. 1945. Olsservations on soil algae. I.
The ecology, size and taxonomy of British soil diatoms. Neze Phytol. 44:196-219.

13. Mǘler, O. 1903. Sprungweise Mutation bei Melosireen Ber. Deutsch. Bot. Ges. 21:326.

14. Pritzer. E. 1871. Untersuchungen iiber Bau und Entwicklung der Bacillariaceen (Diatomaceen). In Hanstein, J. L. E. R., von., Botanische Abhandlang aus dem Gebied der Morphologie und Physiologie. A. Marcus, Bonm, 189 pi).

15. SkvorTzow, B. J. 1927. Diatoms from Tientsin, Noith China. J. Bot. 65:102-9.

16. Smith, Wur. 1856. A synopsis of the British Dialomaceae J. Van Voorst, London, Vol. II, $107 \mathrm{pp}$.

17. Stoermer, E. F., Pankratz, H. S.. \& Drum, R. W. 1964. The line structure of Mastogloia grevillei Wm. Smith. Protoplasma 59:1-13.

18. —— - - Bowen, C. C. 1965. Fine structure of the diatom Amphipleura pellucida. II. Cytoplasmic fine structure and frustule formation. Am. J. Bot. 52:1067-78.

19. Srosch, H. A. voN. 1965. Manipulierung der Zellgrösse von Diatommen im Experiment. Phycologica 5:21-44.

20. Thwaites. G. H. K. 1848. Further observations on the Diatomaceae, with descriptions of new genera and species. Ann. Mag. Nat. Hist 20:161-72.

21. VAN DER WERFF, A. 1955. A new method of concentrating and cleaning diatoms and other organisms. J'erhandl. Intern, ler. Limnol. 12:276-7.

22. Voicr, M. 1955. Some Mastogloia from Pakistan. J. Rov. Microscop. Sor. 75:189-93.

I. Plicol. 3, 77-81 (1967)

\title{
BIOLUMINESCENCE AND CHLOROPLAST MOVEMENT IN THE DINOFLAGELLATE PYROCYSTIS LUNULA ${ }^{1}$
}

\author{
Elijah Sivift and $W$. Rowland Taylor \\ Department of Oceanography, Chesapeake Bay Institute. The Johns Hopkins
}

University, Baltimore, Maryland 21218

SUMMARY

The lunate cysts of Pyrocystis lunula have a bioluminescent emission spectrum with a peak intensity of $477.5 \pm 1 \mathrm{~m}_{\mu}$. The light originates from the protoplasm in the center of the cysts. Six to eight hr after the cysts were placed in the dark, they produced 300 to soo times more luminescence than controls maintained under constant illumination. Plastids contract distally when the cysts are placed in the dark. If kept in the dark, the plastids contract distally and expand with a circadian rhythm persisting several dirys. At intensities of $2200 \mu \mathrm{i} \omega \mathrm{cm}^{-2}$ or less, the plastids are expanded. The plastids are contracted into the central area of the cysts at light intensities of

\footnotetext{
${ }^{1}$ Contribution No. 103. This work was partially supported by contracts between the Atomic Energy Commission and the Chesapeake Bay Institute of The Johns Hopkins University, AT(30-1)-3497 Doc. No. NYO-3497-10. Rereived March f, 1967: revised A pril $2 \$, 1967$.
}

$4000 \mu \mathrm{w} \mathrm{cm}^{-2}$ and above. The Gymnodinium stage of the life cycle is not bioluminescent.

\section{INTRODUCTION}

During the Challenger Expedition (1872-1876), Murray (12) first described the genus Pyrocystis and noted that ". . . these forms are highly phos. phorescent." Schütt described the species Pyrocystis linnula from the plankton of the Humboldt Current in 1895. Since then, P. lunula has proved to be a cosmopolitan marine species (11). Three stages in the life cycle are known: Gymnodinium-type swarmers, crescent-shaped cysts, and large spherical cysts up to $200 \mu$ in cliameter (for review, see 11). We have isolated $P$. lunula and report here some observations on the crescent-shaped cysts and the Gymnodinium stage of the life cycle. 